\title{
The Pre-School Teachers' Understanding on Early Literacy: Implementation and Obstacles in Teaching-Learning Activities
}

\author{
Nia Kurniawati \\ Universitas Suryakancana \\ garyadinia2011@gmail.com
}

\begin{abstract}
Early literacy plays a key role in enabling early learning experiences that research shows are linked with academic achievement, reduced grade retention, higher graduation rates, and enhanced productivity in adult life (Strickland \& Riley-Ayers, 2006). This case study focused on pre-school teachers' understanding on early literacy policy, and the basic concepts. It also investigated the implementation of early literacy concept in teaching-learning activities, and the difficulties encountered by teachers during the implementation. This study employed a qualitative design. Ten pre-school teachers were involved in this study. They came from several pre-schools in suburb areas. For validity purpose, data triangulation was applied. Therefore, this current study used several instruments, including open-ended questionnaires, nonparticipant classroom observations, and semi structure interviews conducted immediately after the completion of all activities in the classroom observations. It was found that the pre-school teachers' understanding on early literacy policy and concept still needs to be improved. It can be seen from the partial implementation of the concept in teaching-learning processes, most pre-school teachers considered that early literacy only covered pre-schoolers' ability to read and to write printed material. Some obstacles were also found in the implementation of the right concept related to the early literacy; those obstacles were mainly caused by the teachers' unsuitable education level, parents' high expectation, and lack of facilities. Based on the findings, it is recommended that the early literacy policy and concepts should be comprehended thoroughly by preschool teachers immediately to enhance the quality of the teaching learning to young learners. It is also recommended that further study include more participants and broader scope.
\end{abstract}

Keywords: pre-school teachers, early literacy, implementation, and obstacles.

\section{INTRODUCTION}

As early childhood education moves forward to the public policy debate, more attention is being paid to early literacy. Early childhood professionals have long recognized the importance of language and literacy in preparing children to succeed in school. Early literacy plays a key role in enabling the kind of early learning experiences that research shows are linked with academic achievement, reduced grade retention, higher graduation rates, and enhanced productivity in adult life.
Based on the focus mentioned above, the purposes of this study are

(1) to portray the pre-school teachers' understanding on early literacy policy, and the basic concepts,

(2) to find out the implementation of early literacy concept in teaching-learning activities, and

(3) to investigate the difficulties that the teachers encountered during the implementation.

Literacy development is less about a limited critical period and more about windows of opportunity that extend across early childhood, culminating perhaps around the age of 10 . So even if a child has limited access to language and literacy experiences in the home, there's much ground to be gained through literacy-rich expanded learning or mentoring opportunities such as preschool, extended day programs, cross-age literacy partners, and the like. During late infancy and late childhood synaptic density reaches a plateau-this is the period of maximal responsiveness to environmental input (Huttenlocker et al., 2002).

Early literacy development is defined as acquisition and mastery of the fundamentals of reading, writing, and other literacy-related skills (Hall, Larson, \& Marsh, 2003 in Dunst, Trivette, Masiello, Roper, \& Robyak, 2006, p.2). According to French $(2013$, p.1) there are six early literacy skills, they are vocabulary, print motivation, print awareness, narrative skills, letter knowledge, and phonological awareness.

\section{METHODS}

The case study design was employed for this research. A case study is variation of an ethnography in that the researcher provides an in-depth exploration of a bounded system (e.g., an activity, an event, a process, or an individual) based on extensive data collection (Cresswell, 2002).

To ensure the internal validity in the research design, several methods of data collection should be used for triangulation purposes (Yin, 2003). In this research, some instruments were used to collect the data, i.e., including open-ended questionnaires, non-participant classroom observations and semi structure interviews conducted immediately after the completion of all activities in the classroom observations.

The research was conducted in a pre-school in Cianjur. As it has been discussed earlier, this research was aimed at finding out the implementation of early literacy at preschool and the obstacles within. Based on those considerations, the 
researcher selected the participant for the present study. The participants of the research will be 4 pre-school teachers, 4 parents and a class of young learners at a preschool.

In the present study, the data analyses were conducted to answer three research questions. The data obtained from classroom observation, questionnaire, and interview. Then the data were categorized into three themes based on the research questions.

\section{RESULT DISCUSSION}

There are some results to answer the current research questions. Data was gained through several instruments such as classroom observation, questionnaire, and interview. The results on this research are as follow:

\subsection{The Preschool Teachers' Understanding on Early Literacy}

In answering the first research question, questionnaire was distributed to the participants in this case 4 preschool teachers. The questionnaire was open ended to dig information on the preschool teachers understanding on the concept of early literacy. The questionnaire consists of 14 items focusing on early literacy concept that should be comprehended and the practice that should be carried out by preschool teachers. It is in form of open ended since this research is qualitative in nature, so the open-ended questions were intended to get detail picture of the respondents on the current issue of the study.

For the issue of early literacy definition, all the participants regard early literacy as merely reading as adult literacy. Data from the questionnaire showed that all respondents answered that early literacy is the ability of young learners to read and to write. However, the participants also consider reading and writing symbols as part of early literacy, and it can be seen at the excerpt below.

\section{Q8: Apa yang anda pahami tentang literasi dini? \\ T1: Membaca. \\ T2: Literasi itu kemampuan membaca, sedang literasi dini itu kemampuan anak untuk membaca.}

The belief that early literacy is similar to conventional literacy showed that the teachers' understanding on early literacy is still needed to be corrected. Moreover, these teachers are dealing with early learners. They are supposed to have good understanding on what early literacy as what children know about reading and writing before they actually read or write (Cedar Mill, 2016). Therefore, early literacy is not the children's ability to read and write. It is more to their preparation to read and write, cognitively, and affectively.

\subsection{The Implementation of Early Education to Young Learners}

This part presents the finding on the implementation of early literacy education at preschool. The instruments used to get the data on this issue were classroom observation. The observations were conducted three times.

Before conducting the observation, the researcher studied the documents the teachers have prepared beforehand. It includes semester program book, and lesson plan. The semester program book defined the early years students' literacy should cover the following.

1. The ability to recognize symbols.

2. The ability to recognize animal sound and the basic vocabularies.

3. The ability to make meaningful scribbling.

4. The ability to imitate letter

The practice of early literacy education to preschool' students still should be reconsidered. Most preschool teachers regard early literacy just like conventional literacy, therefore the way they implement it so much include the practice of reading and writing printed material as adult.

\subsection{The Obstacles in Implementing Early Literacy at Preschool}

In finding out the obstacles during the implementation of early literacy education at preschool, observation and interviews were conducted. The classroom observation was carried out to find out the reality in the classroom in the teaching of early literacy for young children, while the interviews were conducted for triangulation purpose. It involved teachers and parents. Teachers were asked about the common problems that they faced every day and the possible causes to the problems.

There are some main obstacles during the implementation that can be noted as follow.

\subsubsection{The lack of teachers' skill and knowledge on new technique to teach early literacy}

From the interview, there are some surprising facts about the obstacles that the teachers face in implementing early literacy education. From four participants, all of them mentioned that they are lack of new technique in teaching early literacy. They also specified early literacy as reading printed material as adult literacy. It is quite interesting, since almost all of the teachers are S1 degree even they graduated from noneducation study program. They considered themselves lack of knowledge and skills dealing with early literacy teaching.

This kind of inferiority feeling might be resulted from their education background and experience. Even though among the four all of them had graduated from S1 degree, but their degree is not relevant with their responsibilities during the project.

The inappropriate level of education among preschool teachers actually has been national problem of preschool education in Indonesia. It is mentioned by the chairperson of Indonesia PAUD Teachers Association, Netti Herawati, “The first problem is the teacher level of education. It is only 26.06 percent of preschool teachers who have reached s1 degree level, while the National Education Standard required the preschool teachers both formal and non-formal at least should have $\mathrm{S} 1$ degree certificate in psychology or pedagogy. 
This inappropriateness has led the preschool education into a misconception in the practice. The preschool education should give extra portion to activities that alter the young learners with fun activities such as paying, knowing their environment, and learning how to socialize with others has turned into a reading, writing, and counting course for children.

\subsubsection{The lack of facilities within the preschool itself}

The second problem in the implementation of early literacy education at early childhood education is the limited facilities. Ideally, a preschool should have many facilities that would support the young learners' development cognitively, affectively and physically.

\subsubsection{The lack of support from the parents, especially on the reading habit}

The next problem occurred in the implementation of early literacy education is the lack support from the parents, especially on the reading habit. From the interview with the parents, almost none of them like reading at home. They also do not understand about early literacy and even never hear anything about it previously.

Q4: Apakah anda pernah mendengar istilah literasi
dini?
P1: Ya.
P2: Tidak.
P3: Tidak pernah.
P4: Tidak pernah
Q5: Menurut anda apakah literasi dini itu?
P1: Calistung.

From the excerpt above, it can be seen that most parents have never heard about early literacy and have wrong conception about it. It represents what most parents expect from early education.

This lack of reading habit and misconception about early literacy among parents happened because of in this case the parents' level of education. From all participants, only one participant who graduated from university, while the rests are graduated from elementary and junior high school only.

Q7: Apakah anda suka membaca?
P1: Ya
P2: Tidak
P3: Tidak
P4: Tidak

This represents our country's education condition. It is very regretful when the parents reading habit at home is poor because it would influence so much on the children literacy behavior too. Even the children are not ready yet to read printed material, but when they have good reading habit environment, it will build their interest on reading in the future. No wonder, Indonesia has poor level at PISA score.

\subsubsection{The huge number of students within a class}

Another classic problem in early childhood education in Indonesia generally and particularly in the preschool where this research was conducted is the huge number of students within a class. This condition is worsened by the lack number of teachers who handle that huge number of students. Some preschools even should count on only one teacher to handle more than fifteen children.

\section{CONCLUSION}

There are some important points that can be drawn from this current research as follow:

1. Early literacy is still unfamiliar concept even for those who are involved in early childhood education like preschool teachers. Many teachers considered early literacy as reading and writing as adult literacy.

2. The misconception of early literacy has affected the process of learning at many preschools in Indonesia. Many preschools have turned into Calistung (reading, writing, and counting) courses for young learners.

3. There are many obstacles occurred in the implementation of early literacy education. The teacher level of education has been the first factor, because in Indonesia only small amount of preschool teachers graduated from S1 degree. Many of them only graduated from elementary, junior and senior high school. The lack of facilities also has been big problem in conducted early literacy education. Finally, the parent condition also one of the most influencing factor in building early literacy. Many parents due to their economic and educational background have no interest on reading. They want the children to have reading habit, but they do not like reading themselves.

4. From the current research, there are some points to be considered for further research or for those who are involved in early childhood education.

5. The preschool teachers must improve themselves, especially on their level of education. It is suggested that they continue their study to higher education with linear course.

6. The government should provide scholarship to support preschool teachers who want to continue their study.

7. The government also should assist preschool to provide proper facilities to improve the quality of early literacy education, such as library and teaching media be used in the classroom.

8. Parents should change their habit at home. They should give sample to their young children to love reading.

9. For further research, it is better to be conducted in a larger scope with longer time.

\section{REFERENCES}

Cedar Mill Community Libraries. (2016). Building Early Literacy Skill. Retrieved March 27, 2016 from: library.cedarmill.org 
Creswell, J.W. (2002). Educational Research. New Jersey: Pearson education, Inc.

Dunst, C. J., Trivette, C.M., Masiello, T., Roper, N., \& Robyak, A. (2006). Framework for Developing Evidence-Based Early Literacy Learning Practices. CELL Papers, 1 (1), 2.

French, E. (2013). Six Early Literacy Skills. Retrieved from pageahead.org
Huttenlocker, J., Vasilyeva, M., Cymerman, E., \& Levine, S. (2002). Language input and child syntax. Cognitive Psychology, 45, 337-374.

Strickland, D.D \& Riley-Ayers, S. (2006). Early literacy: Policy and practice in the preschool years. Retrieved from: readingrockets.org

Yin, R. K. (2003). Case Study Research Design and Methods. California: Sage Publications, Ltd. 